\author{
Maria Szczepska-Pustkowska \\ ORCID: 0000-0002-8307-6566 \\ Uniwersytet Gdański \\ pedmsp@ug.edu.pl
}

\title{
Dorośli (i dorosłość) w pismach Janusza Korczaka
}

\section{Summary}

Adults (and adulthood) in the writings of Janusz Korczak

Analyzing the texts of Janusz Korczak, we focus mainly on the child (and childhood), which he put in the center of his reflections. He emphasized the importance of childhood humanity (full and not maimed), associated with it: the dignity of the child and respect for him and the world he created. The purpose of this text is to reflect on how Korczak perceived adults and adulthood and what meaning he gave them in his writings. In order to achieve such a goal, a phenomenographic analysis of the content of several leading works of Janusz Korczak was made. It seems that this topic, although not as expressive in his works as the theme of a child and childhood, is equally important, because in the care and education for centuries, children and adults face each other.

Keywords: Korczak, adult - adulthood, child - childhood

Słowa kluczowe: Korczak, dorosły - dorosłość, dziecko - dzieciństwo

Większość opracowań poświęconych Januszowi Korczakowi rozpoczyna się zwykle od jego biografii - złożonej, nieprostej, tragicznej. Zwykle też na plan pierwszy wysuwają się jego miłość do dzieci i heroiczne poświęcenie, które wraz z wychowankami powiodło go z Domu Sierot przy ulicy Siennej 16 na Umschlagplatz i stamtąd ku komorom gazowym Treblinki. Biografowie/korczakolodzy przedstawiają go zwykle jako lekarza (z zawodu), opiekuna i wychowawcę (z powołania), pisarza/publicystę (z talentu) czy wreszcie badacza (z ciekawości Innego i świata). Dodajmy, że dla Korczaka „Innym” było przede wszystkim dziecko - innym człowiekiem, inną, ale nie mniej ważną hipostazą człowieczeństwa (por. Kamińska 2013: 219).

Igor Newerly, wieloletni przyjaciel Korczaka, opiekun i redaktor dziecięcego pisma „Mały Przegląd”, charakteryzuje Starego Doktora takimi oto słowy: „Janusz Korczak nie mieści się w żadnym z trzech zawodów, jakie uprawiał. Nie tylko znakomity pisarz, nie tylko wychowawca reformator i doskonały lekarz: ktoś znacznie bardziej znaczący dla świata niż te trzy zawody. Całą swoją osobowością, drogą życia i śmiercią, stał się fenomenem ogólnoludzkim, mobilizującym dobre uczucia i pragnienia, łączącym ludzi różnych narodowości, wyznań i ustrojów jednoznacznym przekazem człowieczeństwa" (Newerly 1982: 27). 
Słowa te ukazują głęboką prawdę o Korczaku - wokół dobra dzieci potrafił on łączyć wielu różnych ludzi, których dzieliły narodowość, wyznanie, poglądy społeczno-polityczne, stopień zamożności: Polaków i Żydów, „lewicowców” i „konserwatystów”, biednych i zamożnych, dorosłych i dzieci. Łączył ich wszystkich czymś trudnym do zdefiniowania, co Simone Weil określiła jako „odczytywanie powinności” (cyt. za: Smolińska-Theiss 2013) i co stanowi najgłębszą miarę człowieczeństwa.

Celem, jaki sobie postawiłam, przygotowując niniejszy tekst, nie jest kolejne przywoływanie biografii Korczaka, lecz namysł nad tym, jak postrzegał on dorosłych i dorosłość i jaki wymiar nadawał im w swoich pismach. Jak się wydaje, wątek ten, choć nie tak wyrazisty w jego dziełach jak wątek dziecka i dzieciństwa, jest równie istotny, w opiece i wychowaniu bowiem od wieków stają naprzeciw siebie właśnie dzieci i dorośli.

\section{Pisma Janusza Korczaka i ich współczesne odczytania}

Literaturoznawcy sytuują prace Korczaka w kilku zasadniczych obszarach (Kurządkowska 2014: 91). Pierwszy z nich obejmuje jego teksty pedagogiczne, do których zalicza się m.in. esej Jak kochać dziecko - i jego kolejne „odsłony”: Dziecko w rodzinie, Internat, Kolonie letnie, Dom Sierot, Prawidła życia. Pedagogika dla młodzieży i dorostych czy wreszcie Pedagogika żartobliwa.

Drugi z obszarów Korczakowskiej twórczości wypełniają teksty literackie przeznaczone dla dorosłych (rodziców, wychowawców, opiekunów, nauczycieli itp.) oraz teksty dla dzieci i młodzieży (które określa się czasem mianem „,iteratury osobnej”) (por. Cieślikowski, Waksmund 1985). Można tu usytuować takie dzieła Korczaka, jak choćby: Dzieci ulicy; Koszałki opałki; Dziecko salonu; Mośki, Jośki, Srule; Józki, Jaśki, Franki; Sława; Bobo; Kiedy znów będę maty; Bankructwo małego Dżeka; Król Maciuś Pierwszy; Król Maciuś na bezludnej wyspie; Kajtuś Czarodziej; Uparty chłopiec; Ludzie sa dobrzy czy Trzy wyprawy Herszka. Ksiądz-poeta Jan Twardowski tak oto przedstawiał Korczakowski styl pisania dla dzieci: „opowiadać ze szczegółami, a nie ogólnikami. Nazywać świat po imieniu. Nie ptak. Tylko szpak, drozd, słowik. Określić kolory. Nie drzewo, tylko dąb, wiąz" (cyt. za: Grzebałkowska 2011: 135).

Osobną kategorię tworzą dwa ważne teksty Korczaka, a mianowicie jego Pamiętnik pisany w okresie wojennym, zawierający wspomnienia, reminiscencje i opisy doświadczeń Starego Doktora, oraz Momenty wychowawcze, w których Korczak uchylił rąbka tajemnicy swojego warsztatu badawczego (form i metod obserwacji wychowanków' i warsztatu pisarskiego (Kurządkowska 2014: 91).

\footnotetext{
1 Prace Korczaka ujawniają wielką wiarę i ufność w dziecko, w posiadane przez nie możliwości oraz zachwyt różnorodnością, złożonością i bogactwem dziecięcego świata. Ten fascynujący go świat, w którym chętnie uczestniczył i który pragnął zrozumieć, stał się dla Korczaka na wiele lat przedmiotem codziennych bacznych obserwacji, skrupulatnych studiów, ostrożnych interpretacji utrwalanych w dziesiątkach brulionów. Korczak nie szukał w dziecku niedoskonałości, braków, słabości czy deficytów. Przeciwnie -
} 
Powrót do myśli Korczakowskiej zawartej w tekstach dla „dużych i małych” nie jest prostym zadaniem. Korczak nawet dla współczesnych sobie bywał trudny w lekturze i rozumieniu. Najczęściej odczytywano jedynie ich zewnętrzną, najłatwiej uchwytną warstwę, nie dociekając znaczeń osadzonych w głębszych pokładach. Sam Korczak o swoich zapiskach w Pamiętniku pisze: „Przeczytałem. Z trudem zrozumiałem. A czytelnik? Nie dziw, że pamiętnik niezrozumiały dla czytelnika. - Czyż można zrozumieć cudze wspomnienia, obce życie. Zdaje się, że ja bez trudu winienem wiedzieć, co piszę. Ba. Czy można zrozumieć własne wspomnienia?" (Korczak 2012: 94).

Pisma Korczaka powstały w określonym czasie historycznym; to zaś naznaczyło je wydarzeniami współczesnymi jego życiu (Ablewicz 1995: 63-64). Odsłaniają nie tylko obraz ówczesnej (dziecięcej) codzienności czy wpisane w ówczesną kulturę i obyczajowość relacje łączące dzieci i dorosłych, lecz są również ważnym świadectwem stosunku Korczaka do dziecka oraz jego autentycznego zaangażowania w tzw. „sprawy dzieci” (por. Hartman 1999). Każdego, kto sięga po którekolwiek z Korczakowskich dzieł, czeka najpierw namysł nad tym, w jaki sposób czytać i rozumieć je po niemal stu latach od czasu publikacji.

Dzieła, o których mowa, zdane na kolejne nowe odczytania, wyrastają poza i ponad tamten bezpośredni kontekst historyczny, gdyż dziś czyta je i poddaje analizom kolejna generacja czytelników - ci zaś nadają im nowe sensy i znaczenia. W tych okolicznościach tekst przestaje należeć do autora i rozpoczyna egzystencję niezależną - poza nim. Istnieje samodzielnie, wyobcowany ze swego pierwotnego środowiska, bezpośredniego, sytuacyjnego odniesienia oraz kontekstów charakterystycznych dla tamtych czasów (Ricoeur 1985: 318). Również pisma Korczaka, pozostając poza mocą bezpośredniego oddziaływania autora i przekazywanych przezeń intencji, poza prawdą tamtych sytuacji oraz problemów społecznych i wychowawczych, dla dzisiejszych czytelników istnieją już inaczej. $Z$ jednej strony przywracają tamten przeszły świat, z drugiej zaś pomagają odsłonić jakąś prawdę niezależną od minionego kontekstu historyczno-społecznego.

\section{Życie dzieci na marginesie życia dorosłych...}

Korczak o dorosłości i dorosłych pisał niewiele, rzec by można - prawie wcale, a w każdym razie nie wprost. We wszystkich jego tekstach obecni są oczywiście dorośli (rodzice, wychowawcy/nauczyciele, opiekunowie itp. niezbędni w życiu dzieci), jednak to nie na nich autor skupiał swoją uwagę. Na pierwszym planie zawsze sytuował dziecko, a (towarzyszący mu) dorośli odgrywali (ważne) role drugoplanowe. To dziecko (i dzieciństwo) zawsze stanowiło punkt centralny, a zarazem punkt wyjścia dla wszelkich jego przemyśleń, jak pisał bowiem: „Jeśli podzielić ludzkość na dorosłych i dzieci, a życie na dziecięctwo i dojrzałość, to tego dziecka na świecie i w życiu jest bardzo, bardzo dużo" (Korczak 1929: 86). Nawet w powieści Kiedy znów będę mały (Korczak 1961), w której mamy do

wskazywał na jego siłę, możliwości, którymi już dysponuje, i kompetencje, którymi już włada. Postrzegał je jako podmiot aktywny, twórczy, zapytujący o świat i mierzący się z nim i trudami życia. 
czynienia z tym samym bohaterem przedstawionym jednak paralelnie - raz jako dziecko, raz jako dorosły - właśnie postać dziecięca zajmuje pozycję dominującą. Dziecko, które ukochał; dziecko - „,nieskończoność możliwości”, „bezmiar i wieczność” (Korczak 1948: 11); dziecko - „,człowiek pełny” (Korczak 1978b: 198, 202).

Zygmunt Bauman w artykule poświęconym Korczakowi przywołuje wszechobecne mniemanie, że kluczem do jego myśli i czynów była właśnie „miłość dziecka”. Rozważa, co oznacza owo Korczakowe „kochać dziecko”, dochodząc do konkluzji, że tym, co Stary Doktor ukochał w dziecku najbardziej, było jego człowieczeństwo, które ani nie jest związane z czasem, ani nie podlega relatywizacji. Jedynie dziecko występuje w najlepszej z możliwych postaci: całkowite, nieokaleczone, bez uszczerbku, pełne niezawiedzionych jeszcze obietnic i niezmarnowanych możliwości (Bauman 2002: 15). Postrzegając je jako bezcenną wartość, Korczak kategorycznie wzywał, by otoczyć je opieką i zachować w całej jego pierwotnej, nieuszczuplonej pełni, by chronić je przed zniszczeniem, redukcją i degradacją.

W eseju The Inhuman Reflections on Time Jeana-François Lyotarda czytamy, że: „dziecko jest dogłębnie człowiecze, bowiem jego zakłopotanie zapowiada i obiecuje nadejście tego, co możliwe" (Lyotard 1991: 3-4). Dostrzegał to również Korczak, który zwracał uwagę, że wszystko jeszcze jest przed dzieckiem i że wszystko jest możliwe, ponieważ żadna z dróg prowadzących w przyszłość jeszcze się dla niego nie zamknęła. Przestrzegał jednak, by nie rozpatrywać go jedynie w kategoriach przyszłościowych - przez pryzmat umiejętności, kompetencji, osiągnięć, sukcesów, wartości, które kiedyś (w dorosłości) staną się jego udziałem. Pytał: „Czym (...) dziś dziecka jest gorsze, mniej cenne od jutra... Bo zasadniczy pogląd: dziecko nie jest, a będzie, nie wie, a będzie wiedziało. Nie może, a dopiero będzie mogło - zmusza do ciągłego oczekiwania" (Korczak 1929: 58). Takie podejście uważał za poważny błąd, w którego wyniku dokonuje się redukcji dziecka w płaszczyźnie osobowej i społecznej. Wyjaśniał, że w tej redukującej je perspektywie (oczekiwania) „terminuje” ono do dorosłości, do przyszłego człowieczeństwa. Pisał, by nie oddawać go w „niewolę jutra” (Korczak 1948: 30) i konsekwentnie akcentował, że dziecko nie będzie dopiero, lecz już jest pełnym człowiekiem; że pyta ono, błądzi, poznaje; że jego dusza jest na równi złożona jak dusza dorosłego i konfrontuje się z tymi samymi problemami świata, z którymi borykają się dorośli.

Dowodząc, że dziecko jest człowiekiem, a nie jedynie zadatkiem na człowieka, Korczak zwracał również uwagę na fakt, że posiada ono swoją godność, którą traktował jako podstawową wartość ontyczną - wrodzoną i trwałą, niezbywalną i zobowiązującą, która wynika wprost z bycia człowiekiem (Korczak 1948: 30). Warto przy tym zauważyć, że upominał się konsekwentnie o tak rozumianą godność dziecka nie tylko ze względu na jego prawa. Godność dziecka Korczak nierozerwalnie wiązał z jego wolnością i podmiotowością, którą postrzegał jako podstawę praw dziecka: do szacunku, obywatelskiego miejsca w rodzinie, społeczności lokalnej, społeczeństwie itp. Z godnością Korczak wiązał dziecięce obywatelstwo, wskazując, że praktyka życia codziennego redukuje dzieci w każdej możliwej płaszczyźnie. Stawiał rewolucyjną tezę jak na czasy, w których działał, że dzieci, podobnie jak inne mniejszości, nie mają żadnych praw (Korczak 1948: 7-8). 
Korczak walczył o godność dziecka także (wbrew powszechnym na początku XX stulecia przeświadczeniom) w imię dobra dorosłych, którymi w przyszłości staną się dzieci. Apelował, by traktować je na równi z dorosłymi, choć kwestii godności i praw dorosłych nie pojmował jako bezproblemowej. Wczytując się w myśl Korczaka, Bauman konkluduje, że godność dzieci należy rozumieć jako dzieciństwo godności ludzi dojrzałych, nie posiada ona bowiem innych korzeni niż godność dziecka. Nie może zatem ani wyrosnąć, ani rozwinąć się na żadnym innym gruncie (Bauman 2002: 15). Ta Baumanowska konkluzja zdaje się być odpowiedzią na Korczakowe zapytanie zawarte w Pedagogice żartobliwej: „Albo życie dorosłych na marginesie życia dziecięcego. Albo życie dzieci - na marginesie życia dorosłych. Kiedy nadejdzie owa szczera chwila, gdy życie dorosłych i dzieci stanowić będzie równoważny tekst" (Korczak 1958: 154).

Od przyjętych przez siebie zasad: uznania godności dziecka, konieczności jego obrony wobec dorosłych oraz wczuwania się w przeżycia dziecięce, Stary Doktor nie odstępował nigdy. Wypełniał je też stale i na nowo kolejnymi doświadczeniami twórczej praktyki wychowawczej. Można powiedzieć, że zasady te stanowią konieczny warunek dialogu dorosłego z dzieckiem.

\section{Dorosły versus dziecko czy dorosły i dziecko w dialogu...}

Niektórzy literaturoznawcy podkreślają, że: „relacja dziecka z dorosłym funkcjonuje w twórczości Korczaka na zasadzie konfliktu" (Czernow 2011: 14), a nawet więcej że konflikt ten jest wręcz główną cechą twórczości Korczaka, podporządkowującą sobie wszystkie elementy jego strategii pisarskiej (por. Onichimowska 1979). Hanna Kirchner, charakteryzując jego twórczość, zauważa, że w postaciach dziecięcych Korczak ukazywał nie tylko dziecko swego czasu (określone historycznie i socjologicznie), lecz przede wszystkim ,uniwersalnego mieszkańca krainy dzieciństwa, która zawsze i wszędzie różni się od świata dorosłych" (Kirchner 2019).

Bohater powieści Kiedy znów będę maty mówi: „Przykro, że się wszystkie nasze sprawy załatwia prędko i byle jak, że dla dorosłych nasze życie, troski i niepowodzenia są jakby tylko dodatkiem do ich prawdziwych kłopotów. Są niby dwa różne życia: ich - poważne i godne szacunku, i nasze - niby żart. Że mniejsi i słabsi, więc jakby zabawka tylko. Stąd lekceważenie. Dzieci - to przyszli ludzie. Więc dopiero będą, więc jakby ich jeszcze nie było. A przecież jesteśmy: żyjemy, czujemy, cierpimy. Lata nasze dziecinne - są to lata naprawdę życia" (Korczak 1961: 80).

$\mathrm{Z}$ takiego podejścia dorosłych do dzieci bierze się lekceważenie, a nawet pogarda wobec nich. Wspomniana odrębność i odmienność światów dorosłych i dzieci jest przyczyną nie tylko lekceważenia najmłodszych, lecz również ich przejmującej samotności, którą Joanna Olczak-Ronikier postrzega jako kolejną z myśli przewodnich twórczości Korczaka, „zakotwiczoną" w przeżyciach i pamięci dzieciństwa Starego Doktora (Olczak-Ronikier 2002: 61).

Nic dziwnego, że Korczak tezę nie ma dzieci - sa ludzie i dziecko jest czlowiekiem kierował głównie do dorosłych, których - przez pryzmat doświadczeń praktyka lekarza 
i wychowawcy - postrzegał jako niegotowych na pełne i autentyczne spotkanie z dziećmi. „Odwołując się do praktyki, występuje jako ich oskarżyciel. Pokazuje, jak rozumiane jest dziecko, jakie jest jego społeczne miejsce i jaką rolę odgrywa w konfrontacji z dorosłym. Zwraca uwagę na brak wiedzy dorosłych na temat dziecka, na przekłamania i uproszczenia. Poddaje refleksji utwierdzone przez kulturę pozorne prawo zawłaszczania dziecka, panowania nad nim. Można powiedzieć, że ujawnia przemoc symboliczną wobec dziecka" (Smolińska-Theiss 2013: 121). Stawiając dorosłych w opozycji do dzieci, Korczak głosi nie tylko krytykę tych pierwszych: równocześnie bowiem oskarża o marginalizowanie dziecka (i dzieciństwa) dominującą przez wieki kulturę i obecne w niej praktyki wychowawcze (Smolińska-Theiss 2013: 121; por. Ariés 2010).

Korczak wielokrotnie powtarzał, że (w świecie dorosłych) dziecko nie ma głosu, że się po prostu nie liczy, że się je lekceważy. Dorosłych (rodziców i wychowawców) piętnował za to, że nie ufają dziecku, że je (bezpodstawnie) podejrzewają, oskarżają, śledzą; że mu zabraniają lub je zmuszają (Korczak 1978a: 62). Pokazywał ich bezmyślność i niejednokrotnie brutalność w postępowaniu z dziećmi. Kreśląc pośrednio portret dorosłych, nie szczędził ostrej krytyki pod ich adresem. Stawiając im zarzuty, piętnował ich posesywistyczne zapędy i próby panowania nad dzieckiem (Korczak 1978a: 94 i 254, cyt. za: Falkowska 1983: 75), niesymetryczne stosunki, a także fałsz i obłudę panujące między dorosłymi i dziećmi (Smolińska-Theiss 2013: 122).

W tych okolicznościach Korczakowska teza: nie ma dziecka - jest czlowiek, uprawomocniła dziecko i dzieciństwo. Człowieczeństwo przybrało tu dwojakie znaczenie. Z jednej strony wiązało się z nadaniem dziecku i dzieciom jako grupie społecznej najwyższej wartości, z uznaniem dziecka za pełnowartościowego człowieka, dzieciństwa zaś za istotny okres w rozwoju. Z drugiej oznaczało „status społeczny, rangę i prestiż dziecka oraz dzieci jako grupy społecznej” (Smolińska-Theiss 2013: 124). Korczak zatem nie tylko nadał dzieciństwu rangę człowieczeństwa, lecz także zrównał wartość dziecka z wartością dorosłego. Niekiedy sądzi się, że w pedagogii Korczaka dziecko nie pozostawało wyłącznie partnerem dorosłego, a relacja między nimi nie była zupełnie symetryczna (Kamińska 2013: 221). Korczak pisał: „W dziedzinie uczuć przewyższa nas siłą przez nieurobienie hamulców. W dziedzinie intelektu co najmniej nam dorównywa, tylko brak mu doświadczenia. Dlatego tak często dojrzały bywa dzieckiem, a ono dojrzałym człowiekiem. Cała reszta różnicy, to że nie zarobkuje, że będąc na utrzymaniu, zmuszone ulegać" (Korczak 1929: 87-88). Dziecko jest tu jednocześnie czymś więcej i czymś mniej niż dorosły. Dorosły przewyższa je swoim doświadczeniem życiowym i wiedzą; ono jednak przerasta go swoją spontanicznością i kreatywnością myślenia. „Gdyby nie było tej asymetrii, gdyby uczeń i nauczyciel byli po prostu i tylko partnerami, nie istniałaby relacja wychowawcza, a to przecież nauczyciel jest tym, który odpowiada za proces wychowawczy, i na nim spoczywa zadanie wydźwignięcia wychowanka ku wyższym wartościom. Dlatego niezbędne jest tutaj wyważenie pomiędzy permisywizmem a autorytaryzmem" - dowodzi Anna Kamińska (2013: 221). 
Inaczej kwestię tę wyjaśnia Janusz Tarnowski, który, przywołując liczne Korczakowskie przykłady, stwierdza, że dzieci bardzo potrzebują i pragną dialogu z dorosłymi-rodzicami, wychowawcą-opiekunem, nauczycielem i chodzi tu nie tylko o łączność wyrażoną słowem, lecz także o wspólne podążanie do wzajemnego zrozumienia, zbliżenia, współdziałania, w którym zakłada się właśnie jakąś równość partnerów (Tarnowski 1988: 68-69). Tarnowski wyjaśnia, że oprócz powszechnie przyjętego modelu relacji, w którym dorosły znajdował się „na górze”, a dziecko „na dole” i w którym przepływ wiedzy od góry ku dołowi, od dorosłego do dziecka, miał swoje znakomite zastosowanie w placówkach prowadzonych przez Starego Doktora, Korczak wypracował również dwa nowe modele owych relacji. W pierwszym z nich dziecko „»na górze « - dorosły »na dole«", to właśnie dziecko było „nauczycielem swojego nauczyciela” i „wychowawcą swojego wychowawcy”. Przepływ wiedzy i doświadczenia od dołu do góry, a więc od dziecka do dorosłego, Korczak komentował następująco: „Dziecko daje mi doświadczenie, wpływa na moje poglądy, świat moich uczuć; od dziecka otrzymuję nakazy dla siebie, żądam, oskarżam się, pobłażam lub rozgrzeszam. Dziecko poucza i wychowuje" (Korczak 1925/1926: 69). W drugim modelu „dorosły »obok «” dziecka przepływ wiedzy był dwukierunkowy, a dorosły i dziecko uczyli się od siebie nawzajem, czego najlepszych przykładów dostarczały działające w placówkach Korczakowskich Sejm Dziecięcy, Sąd Koleżeński i inne dziecięce instytucje czy wspólna z dziećmi praca redakcyjna nad „Małym Przeglądem” (Tarnowski 1988: 69-70). W każdym jednak ze wspomnianych modeli Korczak przypominał dorosłym/wychowawcom: „Ale niech ma zawsze świadomość, że może się mylić” (Korczak 1978a: 252).

Na dialog między dorosłym i dzieckiem można spojrzeć wreszcie przez pryzmat dialogicznej postawy Korczaka w stosunku do dziecka-człowieka. Z tej postawy wyłaniają się trzy rodzaje dialogu, które Stary Doktor zalecał dorosłym w relacjach z dziećmi. Są to dialogi: rzeczowy (zwrócony ku wiedzy o rzeczywistości będącej jego przedmiotem), personalny (zwrócony przede wszystkim ku osobom partnerów - dzieci) i egzystencjalny (który angażuje w pełnym wymiarze i bez reszty egzystencję prowadzących go osób, gotowych do całkowitego wzajemnego oddania) (Tarnowski 1988: 68).

Korczak nie tylko pisał o nich na swój niełatwy sposób, zachęcając dorosłych do podjęcia trudu pozostawania $\mathrm{z}$ dziećmi w autentycznym dialogu, lecz - co najważniejsze - w swojej pracy z wychowankami trwał z nimi - jak się okazało w najtrudniejszym ze wspomnianych rodzajów dialogu - w dialogu egzystencjalnym. Nie tylko uczył więc swoich wychowanków mądrości życia, dobroci, obowiązkowości, uczciwości i innych wartościowych prawideł życia, zastanawiając się równocześnie nad tym, kiedy rozmawiać z dziećmi, o czym z nimi dyskutować, jak i po co to robić, lecz poszukiwał warunków, które sprawią, że diametralnie różne osoby - dorosły i dziecko² - zbliżą się do siebie,

\footnotetext{
2 „Badacze orzekli, że człowiek dojrzały kieruje się pobudkami, dziecko popędami, dorosły logiczny, dziecko narwane w złudnej wyobraźni; dorosły ma charakter, ustalone oblicze moralne, dziecko wikła się w chaosie instynktów i chceń. Badają dziecko nie jako odmienną, ale niższą, słabszą, biedniejszą organizację psychiczną. „Niby: dorośli wszyscy - uczone profesory. A dorosły bigos, zaścianek poglądów
} 
zrozumieją się i podejmą współdziałanie. Za najwyższą nagrodę dla dorosłego uważał moment, kiedy dziecko zaufa mu na tyle, by powierzyć mu swoją tajemnicę.

O ile w dialogu rzeczowym trudność dostrzegał w tym, by przezwyciężyć różnicę stopnia wiedzy i doświadczenia, jaka dzieli dorosłego i dziecko, o tyle przeszkód w dialogu personalnym, jak się wydaje, upatrywał w dysproporcji ich osobowości. W dialogu egzystencjalnym natomiast nie liczą się żadne różnice między partnerami, choć bywa, że te istniejące stają się ważnym impulsem do pełniejszego oddania. Dialog egzystencjalny sięga bowiem do głębi własnego ,ja” i polega na wzajemnym darze z własnej egzystencji partnerów. „Tutaj są złączeni dialogiem już nie: ekspert - laik (dialog rzeczowy), wychowawca - wychowanek (dialog personalny), ale po prostu - ludzie o równej przecież w zasadzie randze egzystencjalnej” (Tarnowski 1988: 81).

Śmierć Korczaka i Wilczyńskiej wraz z wychowankami, którą najczęściej wpisuje się w płytkie ramy poświęcenia, w rzeczywistości była czymś dużo głębszym i bardziej znaczącym. Sądzę, że można ją tłumaczyć jako naturalne (konieczne wręcz) następstwo dogłębnego egzystencjalnego złączenia z wychowankami w sytuacji najwyższego zagrożenia, cierpienia i śmierci oraz Weilowskiego „odczytywania powinności” wobec nich. Utożsamiając się egzystencjalnie z wychowankami, nie chcieli i nie mogli pozostawić swoich dzieci samych w obliczu nieuchronnej zagłady - tak jakby swoją śmiercią wypowiedzieli ostatnie zdanie łączącego ich dialogu. „(...) trzeba dać pokrycie na to, co w ciągu mego życia wyznawałem i głosiłem, to jest wierności dziecku-człowiekowi” (Jaworski 1977: 8).

\section{Kiedy znów będę maly... zamiast podsumowania}

Kończąc niniejszy tekst, coraz bardziej odczuwam, że jestem zaledwie na początku pracy nad zagadnieniem i słyszę szept Korczaka - pamiętaj, że możesz się mylić. Dlatego chciałabym tu uniknąć wyciągania jednoznacznych i ostatecznych wniosków i odwołać się do słów bohatera „próby powieści psychologicznej” - jak ją określał Korczak - Kiedy znów będę mały: „A pomyśleć tylko, jakie to dziwne! Chciałem być dzieckiem, a teraz znów myślę, co będę robił, gdy dorosnę. Widocznie i dzieciom, i dorosłym dzieje się nie najlepiej. Ci mają swoje troski i smutki, i ci swoje. Mogłoby być nawet tak, żeby człowiek na zmianę raz był duży, raz mały. Jak jest zima i lato, dzień i noc, sen i czuwanie. Gdyby tak było, nikt by się nie dziwił. Tylko lepiej by się rozumieli wzajemnie dorośli i dzieci” (Korczak 1961: 32).

Słowa te najtrafniej chyba ukazują pomysł Korczaka na relacje dziecko-dorosły. Spotykamy tu dwa przenikające się wzajemnie światy - dziecka i dorosłego oraz dzieciństwa

i przekonań, psychologia stada, przesądy i nawyki, lekkomyślne czyny ojców i matek, całe od dołu do góry nieodpowiedzialne życie dorosłe. Niedbalstwo, lenistwo, tępy upór, bezmyślność, dorosłe niedorzeczności, szaleństwa i pijane wybryki. A powaga, rozwaga i równowaga dziecięca, solidne zobowiązania, doświadczenie na własnym odcinku, kapitał sprawiedliwych sądów i ocen, taktowna powściągliwość w żądaniach, subtelne odczuwania, niemylne poczucie słuszności. Czy każdy wygra, grając z dzieckiem w szachy?" (Korczak 1948: 14). 
i dorosłości. Choć wypełnione odmiennymi doświadczeniami egzystencjalnymi (a może raczej doświadczeniami egzystencjalnymi oglądanymi, rozpatrywanymi i rozumianymi z dwóch różnych perspektyw), łączy je tak ważna dla Korczaka ontyczna kategoria człowieczeństwa. Odkrycie tych perspektyw, tj. spojrzenia na świat dorosłych oczami dziecka i dostrzeżenia dziecięcego świata przez dorosłych, stanowi - jak się wydaje - o sile pedagogii Korczaka. Spotkanie tych perspektyw staje się bowiem fundamentem specjalnej wspólnoty doświadczeń dziecka i dorosłego, z której rodzi się i rozwija dialog człowieczeństwa dorosły i dziecko podejmują w nim trud odkrywania i rozumienia się nawzajem.

\section{Literatura}

Ablewicz K. (1995), Teksty Janusza Korczaka jako przesłanie i inspiracja na przykładzie doświadczenia cierpienia dziecka. „Rocznik Komisji Nauk Pedagogicznych”, 48.

Ariés P. (2010), Historia dzieciństwa. Tłum. M. Ochab. Warszawa, Wydawnictwo Aletheia.

Bauman Z. (2002), Dzieciństwo godności ludzkiej. „Midrasz”, 12(68).

Cieślikowski J., Waksmund R. (1985), Literatura osobna. Warszawa, Nasza Księgarnia.

Czernow A.M. (2011), Pod berłem króla dzieci. Strategie karnawalizacyjne w powieści Janusza Korczaka. „Guliwer”, 4.

Grzebałkowska M. (2011), Ksiądz paradoks. Biografia Jana Twardowskiego. Kraków, Znak.

Hartman S.G. (1999), Om barnens rätt till respekt. „Locus”, 4.

Jaworski M. (1977), Janusz Korczak. Warszawa, Interpress.

Kamińska A. (2013), Korczakowski dialog z dzieckiem - inspiracje filozoficzne. W: Rok Janusza Korczaka 2012. Nie ma dzieci - sa ludzie. Warszawa, Biuro Rzecznika Praw Dziecka.

Kirchner H. (2019), Korczak - pisarz. http://www.pskorczak.org.pl/strony/janusz_korczak_nojk08. htm, 25.04.2019.

Korczak J. (1925/1926), Sprawozdanie z I Polskiego Zjazdu Nauczycieli Szkół Specjalnych. „Szkoła Specjalna”, 2.

Korczak J. (1929), Jak kochać dziecko. Dziecko w rodzinie. Warszawa-Kraków, Wydawnictwo J. Mortkowicza, Towarzystwo Wydawnicze w Warszawie.

Korczak J. (1948), Prawo dziecka do szacunku. Spółdzielnia Wydawnicza „Książka”, WarszawaKraków, dostępne również na stronie: http://wolnelektury.pl/katalog/lektura/prawo-dziecka-szacunku, 25.04.2019.

Korczak J. (1958), Pedagogika żartobliwa. W: J. Korczak, Wybór pism. T. 4. Warszawa, PZWS.

Korczak J. (1961), Kiedy znów będę mały, http://wolnelektury.pl/katalog/lektura/korczak-kiedy-znow-bede-maly, 25.04.2019.

Korczak J. (1978a), Pisma wybrane. T. 1. Warszawa, Nasza Księgarnia

Korczak J. (1978b), Pisma wybrane. T. 3. Warszawa, Nasza Księgarnia.

Korczak J. (1983), Wiosna i dziecko. W: Myśl pedagogiczna Janusza Korczaka. Nowe źródła. Wybór M. Falkowska. Warszawa, Nasza Księgarnia.

Korczak J. (2012), Pamiętnik i inne pisma z getta. Warszawa, Wydawnictwo ab.

Kurządkowska B. (2014), O aktualności utworów literackich Janusza Korczaka. „Prace Literaturoznawcze", 2.

Lyotard J.-F. (1991), The Inhuman Reflections on Time. Cambridge, Polity Press. 
Newerly I. (1982). O Januszu Korczaku. W: Janusz Korczak-życie i dzieło. Materiały z Międzynarodowej Sesji Naukowej, Warszawa, 12-15 października 1978. Warszawa, WSiP.

Olczak-Ronikier J. (2002), Korczak. Próba biografii. Warszawa, Wydawnictwo ab.

Onichimowska A. (1979), Świat dzieci a świat dorosłych w powieściach Korczaka. W: M. Tyszkowa (red.), Sztuka dla dzieci szkolnych. Teoria - recepcja - oddziaływanie. Warszawa, PWN.

Ricoeur P. (1985), Zdarzenie i sens wypowiedzi. W: P. Ricoeur, Egzystencja i hermeneutyka. Rozprawa o metodzie. Warszawa, Wydawnictwo PAX.

Smolińska-Theiss B. (2013), Korczakowskie narracje pedagogiczne. Kraków, Oficyna Wydawnicza „Impuls”.

Tarnowski J. (1988), Janusz Korczak dzisiaj. Warszawa, Wydawnictwo ATK. 